\title{
KLASZTEREZÉS SZIMULÁLT LEHÜTÉSSEL ÉS GENETIKUS ALGORITMUSSAL
}

\author{
Agárdi Anita \\ tanársegéd, Miskolci Egyetem, Informatika Intézet, Általános Informatikai Intézeti Tanszék \\ 3515 Miskolc, Miskolc-Egyetemváros, e-mail: agardianita@iit.uni-miskolc.hu
}

\begin{abstract}
Absztrakt
A cikk a klaszterezés témakörével foglalkozik. A klaszterezés olyan adatbányászati algoritmus, amely a bemeneti adatokat csoportositja egymáshoz kapcsolódó hasonlóságuk alapján. A kutatásban a klaszterezést viszont nem a szokványos klasszikus módszerrel oldottam meg, hanem metaheurisztikákkal. A metaheurisztikák közül a szimulált lehütés és a genetikus algoritmus lett kiválasztva. A cikkben három adatsorra mutatok futási eredményeket, melyek alapján megállapitható, hogy az algoritmusok egész szépen megtalálják a klaszterhatárokat.
\end{abstract}

Kulcsszavak: klaszterezés, genetikus algoritmus, szimulált lehütés

\section{Abstract}

The article focuses on clustering algorithms. Clustering is a data mining algorithm that groups input data based on their related similarities. In the research, however, the clustering was not solved by the usual classical method, but by metaheuristics. From the metaheuristics, the simulated annealing and the genetic algorithm were selected. In this article, I present test results for three data sets, based on which it can be concluded that the algorithms find the cluster boundaries efficiently.

Keywords: clustering, genetic algorithm, simulated annealing

\section{Bevezetés}

A cikk a klaszterezés témakörével foglalkozik. A klaszterezés olyan adatbányászati algoritmus, amely során csoportok kialakítása a cél. A csoportokat úgy kell kialakítani, hogy az egymáshoz hasonló elemek azonos klaszterbe, míg a különböző elemek különböző klaszterbe kerüljenek. A klasszikus klaszterező algoritmusokon felül, mint a partíciós, hierarchikus, sürüség alapú, rács alapú stb, a metaheurisztikák irányába is folynak kutatások. A metaheurisztikus algoritmusok számos feladatra adaptálhatóak, így akár klaszterezésre is. Ilyen algoritmusok például a genetikus algoritmus [1-2], szimulált lehütés [3-5], részecske-raj alapú optimalizálás [6-7], hangya kolónia [8-9], tabu keresés [11-12], harmónia keresés [13-14], flower pollination [15-16], memetikus algoritmus [17] stb.

Az 1. ábra a megjelent publikációkat évenkénti bontásban mutatja. A kereséshez a Google scholar adatbázist használtam, a keresés kulcsszavának pedig a következőt adtam meg: „metaheuristic clustering". Látható, hogy 2010-2019-es időszakban folyamatosan növekedett a témában megjelent cikkek száma. 


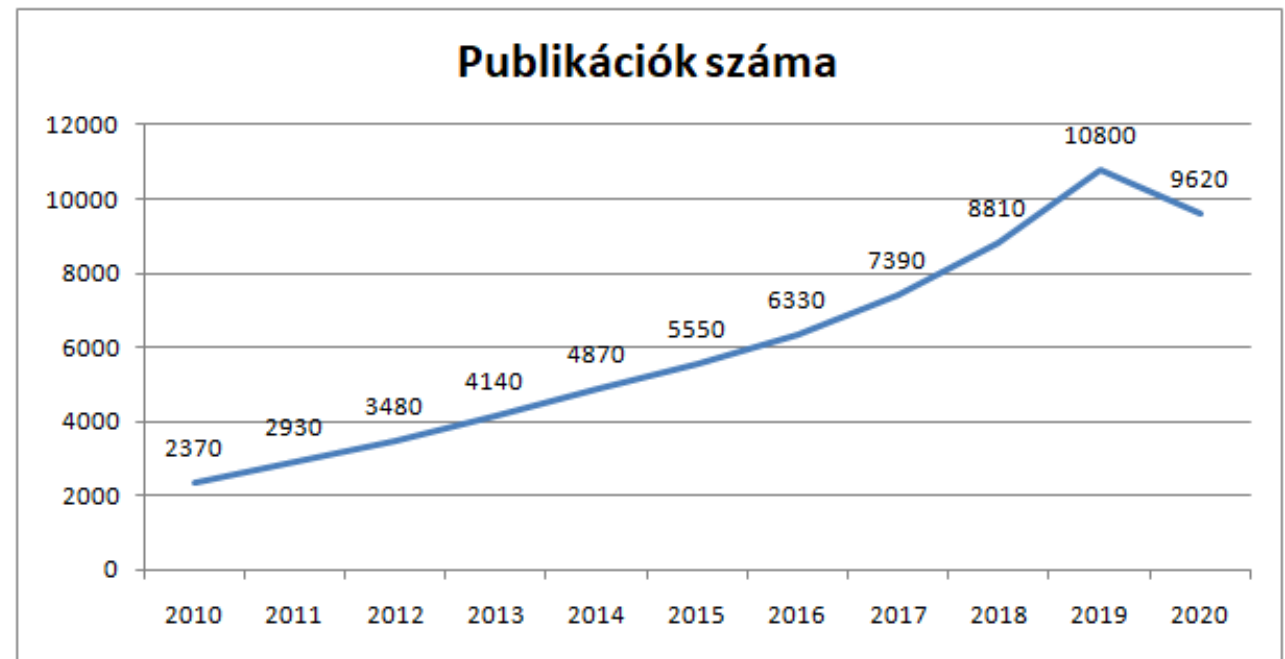

1. ábra. Publikációk évenkénti bontásban (Google scholar adabázis ,,metaheuristic clustering” kereséssel)

Jelen cikkben a metaheuriszikák közül kettőt választottam ki, ez a genetikus algoritmus és a szimulált lehütés. A genetikus algoritmus [1-2] a természetben lezajló evolúciós folyamatokat modellezi. Egy kezdeti populáció generálás után keresztezési és mutációs lépésekkel új egyedek keletkeznek. Az új egyedek egy bizonyos (legrátermettebb) része lesz a következő populáció eleme. A genetikus algoritmus során az alábbi keresztezési operátorokat használtam: sorrendi keresztezés, részleges megfeleltetésủ keresztezés, ciklikus keresztezés. Mutációnak az élcserét alkalmaztam, ami azt jelenti, hogy egy szekvencia elemeit megfordítjuk. A szimulált lehütés [3-5] során egyetlen megoldásból indulunk ki. Kezdetben ez az aktuális megoldás. Az aktuális megoldás egy szomszédját vizsgáljuk. Ha jobb a szomszéd, mint az aktuális megoldás, akkor elfogadjuk. Ha nem jobb, akkor is egy bizonyos valószínüséggel elfogadjuk. A rosszabb megoldás elfogadásának valószínüsége az iterációval csökken. Mivel az algoritmus a rosszabb megoldásokat is képes elfogadni, így könnyedén kijut egy lokális optimumból. Itt szintén az élcsere operátort használtam szomszédság keresésre. A cikk következő fejezetében a futási eredményeket mutatom be.

\section{Futási eredmények}

Ezen fejezet a genetikus algoritmus és a szimulált lehűtés algoritmus eredményeit mutatja be. Három adatsort készítettem, melyek az alábbi paraméterekkel rendelkeznek: pontok száma $(100,50,90)$, klaszterek optimális száma $(10,5,3)$. Az adatsorok jól klaszterezhetőek, mert egyes pontok egymáshoz nagyon közel, míg más pontok nagyon távol találhatóak. A klaszterezés elvált eredménye tehát az, hogy az első adatsort 10, a második adatsort 5, a harmadik adatsort pedig 3 csoportra bontsa. Az elvárás tovább az, hogy az egyes klaszterek szemmel láthatóan is távol legyenek egymástól. A klaszterezés során permutációs ábrázolásmódot használtam. Ez azt jelenti, hogy a permutáció elemei az adatsor egyes elemeit jelenti. A kiértékelés során a permutáció egyes elemeit veszem sorban addig, amíg elég közel helyezkednek el egymáshoz (az adatsor elemei közötti távolságok átlagának negyedik gyöke). Ezek azonos klaszterbe fognak kerülni. Amennyiben a permutáció egy következő eleme már távol helyezkedik el az aktuális elemhez képest, akkor az elem már egy másik klaszterbe fog kerülni. A klaszterezés jóságát is mérni szükséges, hogy az iterációk során meg lehessen különböztetni, hogy 
melyik klaszterezés (permutáció) jelent jó klaszterezést. Erre az egyes klaszterbeli elemek egymáshoz képesti távolságát használom. Az egyes klaszterbeli elemek egymástól vett távolságainak összege lesz a fitnesz érték. Ennek az értéknek a minimalizálása a cél. Az adatsor és a klaszterezés kialakítási stratégia a [18] cikkben bemutatottak alapján készült.

Az algoritmusok nem véletlenszerü megoldásból indulnak ki, hanem egy olyan permutációból (pontok sorrendjéből), amelyet úgy kapunk, hogy körutat képzünk a véletlen pont beszúrása algoritmussal. Az algoritmus során kezdetben egyetlen pontot tartalmaz a körút, majd folyamatosan szúrjuk be az egyes pontokat a körútba arra a helyre, ahol a beszúrás költsége (körút növekedése) minimális [10].

Elsőként az algoritmusok paraméterezését mutatom be, ezután a felhasznált adatsort. Majd a kialakult klaszterezésről ábrákat, és a futási eredményeket táblázatos formában (klaszterek száma, fitnesz érték, futási idő). A felhasznált adatsorok struktúráját a függelék F1 táblázata tartalmazza.

Az 1. táblázat mutatja a Genetikus algoritmus paraméterezését. Iterációszámnak egy nagy értéket adtam, a keresési tér hatékony felkutatása végett. A populációszámnak szintén nagy értéket adtam. Az elitizmus azt jelenti, hogy a populáció bizonyos legjobb egyedei változatlanul kerülnek a következő populációba. Itt egy alacsony számot érdemes megadni. A keresztezésnek egy nagy valószínüséget szokás megadni az algoritmus tervezése során. Az algoritmus $90 \%$ valószínűséggel keresztez összességében (30\% valószínüséggel sorrendi, 30\% valószínüséggel részleges megfeleltetésü és $30 \%$ valószínüséggel ciklikus keresztezést hajt végre). Mutációnak a keresztezéstöl sokkal kisebb értéket szokás adni, én 30\%-ot választottam.

1. táblázat. Genetikus algoritmus paraméterei

\begin{tabular}{|c|c|}
\hline Paraméter & Érték \\
\hline Iterációszám & 100 \\
\hline Populációszám & 60 \\
\hline Elitizmusszám & 10 \\
\hline Sorrendi keresztezési ráta & 0.3 \\
\hline Részleges megfeleltetésü keresztezés ráta & 0.3 \\
\hline Ciklikus keresztezés ráta & 0.3 \\
\hline Mutációs ráta & 0.3 \\
\hline
\end{tabular}

A szimulált lehütés algoritmus paraméterezését a 2. táblázat mutatja. Itt is az iterációszámnak egy nagy értéket adunk a keresési tér hatékony feltérképezése végett. Az alfa érték a hőmérséklet csökkenését jelzi, 15\%-al csökken az egyes iterációknál a hőmérséklet. A hőmérsékletnek egy nagy értéket szokás adni, ez azt jelzi, hogy mennyi az esélye annak, hogy a szomszéd megoldást (amely rosszabb) elfogadjuk. A hossznak egy kis számot szokás megadni, ez azt jelzi, hogy hány iterációnál maradjon változatlan a hőmérséklet. Jelen példában minden 20. iterációnál csökken a hömérséklet 15\%-al.

2. táblázat. Szimulált lehütés algoritmus paraméterei

\begin{tabular}{|c|c|}
\hline Paraméter & Érték \\
\hline Iterációszám & 120 \\
\hline Alfa & 0.85 \\
\hline Hőmérséklet & 1000 \\
\hline Hossz & 20 \\
\hline
\end{tabular}



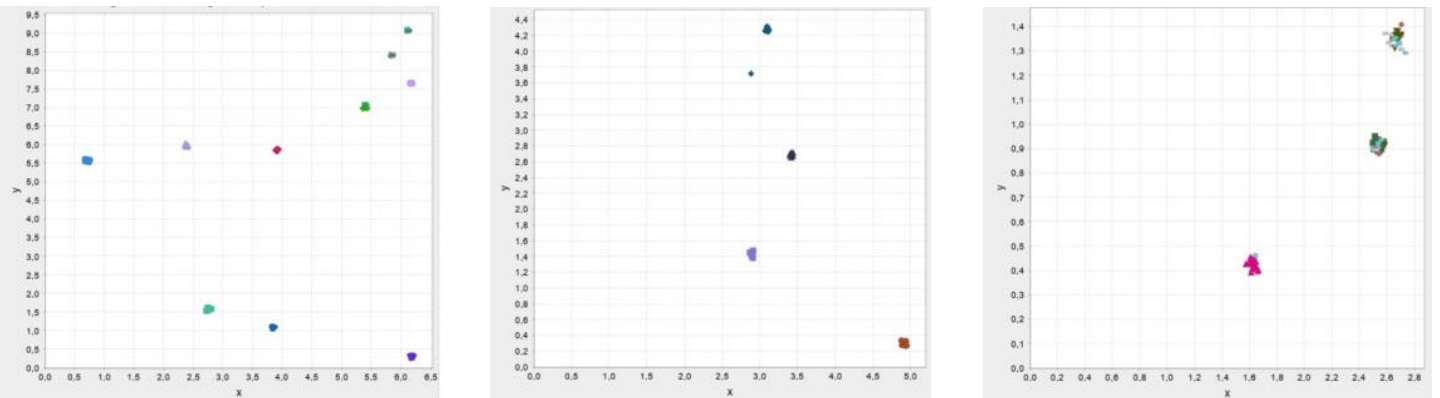

2. ábra. Genetikus algoritmus (Genetic algorithm) eredménye az elsö, második és harmadik adatsorra
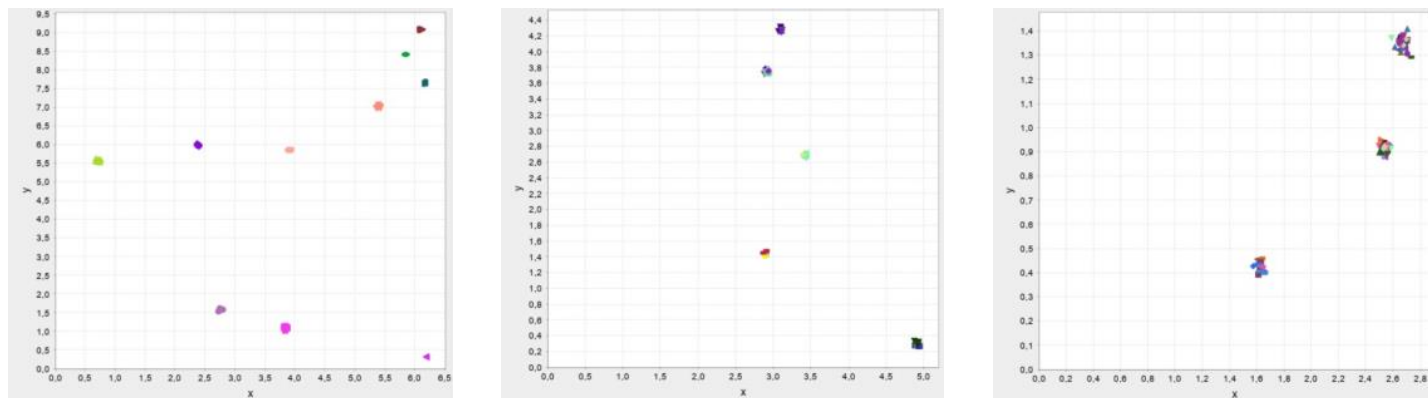

3. ábra. Szimulált lehütés algoritmus (Simulated Annealing algorithm) eredménye az elsö, második és harmadik adatsorra

A futási eredmények alapján a genetikus algoritmus az első két adatsorra hatékonyan megoldotta a feladatot. A harmadik adatsort viszont nem a várt módon klaszterezte. A szimulált lehủtés csak az első adatsort klaszterezte hatékonyan, a második és a harmadik adatsornál viszont nem találta meg a klaszterhatárokat, a vártnál sokkal több klaszter alakult ki. A futási eredményeket táblázatba is foglaltam, ahol a klaszterszámot, fitness értéket és a futási időt is feltüntettem.

3. táblázat. Futási eredmények az elsö adatsorra

\begin{tabular}{|c|c|c|c|}
\hline Algoritmus & Klaszterek száma & Fitnesz érték & Futási idő (perc) \\
\hline Genetic Algorithm & 17 & 0.6583 & 0.0096 \\
\hline Simulated Annealing & 10 & 0.3459 & $9.3251 * 10^{-4}$ \\
\hline
\end{tabular}

Az első adatsort a szimulált lehütésnek sikerült 10 csoportra bontani, de a genetikus algoritmus eredménye ettől jócskán távol maradt (3. táblázat).

4. táblázat. Futási eredmények a második adatsorra

\begin{tabular}{|c|c|c|c|}
\hline Algoritmus & Klaszterek száma & Fitnesz érték & Futási idő (perc) \\
\hline Genetic Algorithm & 4 & 0.6128 & 0.0035 \\
\hline Simulated Annealing & 17 & 0.4082 & $9.9647 * 10^{-4}$ \\
\hline
\end{tabular}

A második adatsornál 5 klaszter lett volna az optimális, a genetikus algoritmus ezt majdnem elérte. A szimulált lehütés ettől nagyon távol maradt, 17 csoportra bontotta az adatsort (4. táblázat). 
5. táblázat. Futási eredmények a harmadik adatsorra

\begin{tabular}{|c|c|c|c|}
\hline Algoritmus & Klaszterek száma & Fitnesz érték & Futási idő (perc) \\
\hline $\begin{array}{c}\text { Genetic Algo- } \\
\text { rithm }\end{array}$ & 7 & 1.1570 & 0.0052 \\
\hline $\begin{array}{c}\text { Simulated Annea- } \\
\text { ling }\end{array}$ & 28 & 0.7223 & $7.2960 * 10^{-4}$ \\
\hline
\end{tabular}

A harmadik adatsornál 3 csoport lett volna az optimális, mindkét algoritmus ettől sokkal több klaszterre bontotta a pontokat, a genetikus algoritmus 7, a szimulált lehủtés pedig 28 csoportot alakított ki. A futási idők mindhárom adatsor esetén alacsonyak voltak (5. táblázat).

\section{3. Összegzés}

Jelen cikkben a klaszterezés, mint az egyik leggyakoribb adatbányászati feladat került középpontba. A cikkben két metaheurisztika került bemutatásra, melyet klaszterezésre használtam. Ez a genetikus algoritmus és a szimulált lehütés. A cikkben három, jól klaszterezhető adatsorra tárgyaltam az algoritmusok hatékonyságát. A futási eredmények alapján az algoritmusok az első két adatsort viszonylag jól csoportosították, míg a harmadik adatsornál sokkal több csoportra bontották a pontokat. A szimulált lehütés az első adatsornál szép eredményt adott, de a második és harmadik adatsornál nem találta meg az optimális klaszterezést.

\section{Köszönetnyilvánítás}

„A cikkben/elöadásban/tanulmányban ismertetett kutató munka az EFOP-3.6.1-16-2016-00011 jelü „Fiatalodó és Megújuló Egyetem - Innovatív Tudásváros - a Miskolci Egyetem intelligens szakosodást szolgáló intézményi fejlesztése" projekt részeként - a Széchenyi 2020 keretében - az Európai Unió támogatásával, az Európai Szociális Alap társfinanszírozásával valósul meg."

\section{Irodalom}

[1] Hruschka, E. R., \& Ebecken, N. F. (2003). A genetic algorithm for cluster analysis. Intelligent Data Analysis, 7(1), 15-25. https://doi.org/10.3233/IDA-2003-7103

[2] Maulik, U., \& Bandyopadhyay, S. (2000). Genetic algorithm-based clustering technique. Pattern recognition, 33(9), 1455-1465. https://doi.org/10.1016/S0031-3203(99)00137-5

[3] Klein, R. W., \& Dubes, R. C. (1989). Experiments in projection and clustering by simulated annealing. Pattern Recognition, 22(2), 213-220. https://doi.org/10.1016/0031-3203(89)90067-8

[4] Brown, D. E., \& Huntley, C. L. (1992). A practical application of simulated annealing to clustering. Pattern recognition, 25(4), 401-412. https://doi.org/10.1016/0031-3203(92)90088-Z

[5] Selim, S. Z., \& Alsultan, K. (1991). A simulated annealing algorithm for the clustering problem. Pattern recognition, 24(10), 1003-1008. https://doi.org/10.1016/0031-3203(91)90097-O

[6] Van der Merwe, D. W., \& Engelbrecht, A. P. (2003, December). Data clustering using particle swarm optimization. In The 2003 Congress on Evolutionary Computation, 2003. CEC'03. (Vol. 1, pp. 215-220). IEEE.

[7] Li, C., \& Yang, S. (2009, May). A clustering particle swarm optimizer for dynamic optimization. In 2009 IEEE congress on evolutionary computation (pp. 439-446). IEEE. https://doi.org/10.1109/CEC.2009.4982979 
[8] Shelokar, P. S., Jayaraman, V. K., \& Kulkarni, B. D. (2004). An ant colony approach for clustering. Analytica Chimica Acta, 509(2), 187-195. https://doi.org/10.1016/j.aca.2003.12.032

[9] İnkaya, T., Kayalıgil, S., \& Özdemirel, N. E. (2015). Ant colony optimization based clustering $\begin{array}{llll}\text { methodology. } & \text { Applied } & \text { Soft } & \text { 301-311. }\end{array}$ https://doi.org/10.1016/j.asoc.2014.11.060

[10] Azar, Y. (1994). Lower Bounds for Insertion Methods for TSP. Combinatorics, Probability \& Computing, 3, 285-292. https://doi.org/10.1017/S096354830000119X

[11] Lu, Y., Cao, B., Rego, C., \& Glover, F. (2018). A Tabu Search based clustering algorithm and its parallel implementation on Spark. Applied Soft Computing, 63, 97-109. https://doi.org/10.1016/j.asoc.2017.11.038

[12] Li, W., Wang, G., \& Li, K. (2017). Clustering algorithm for audio signals based on the sequential Psim matrix and Tabu Search. EURASIP Journal on Audio, Speech, and Music Processing, 2017(1), 26. https://doi.org/10.1186/s13636-017-0123-3

[13] Gupta, G. P., \& Jha, S. (2018). Integrated clustering and routing protocol for wireless sensor networks using Cuckoo and Harmony Search based metaheuristic techniques. Engineering App$\begin{array}{llll}\text { lications } & \text { of } & \text { Artificial }\end{array}$ https://doi.org/10.1016/j.engappai.2017.11.003

[14] Moh'd Alia, O. (2018). A dynamic harmony search-based fuzzy clustering protocol for energyefficient wireless sensor networks. Annals of Telecommunications, 73(5-6), 353-365. https://doi.org/10.1007/s12243-017-0611-6

[15] Kaur, A., Pal, S. K., \& Singh, A. P. (2020). Hybridization of Chaos and Flower Pollination Algorithm over K-Means for data clustering. Applied Soft Computing, 97, 105523. https://doi.org/10.1016/j.asoc.2019.105523

[16] Dhal, K. G., Gálvez, J., \& Das, S. (2019). Toward the modification of flower pollination algorithm in clustering-based image segmentation. Neural Computing and Applications, 1-19.

[17] Sheng, W., Chen, S., Sheng, M., Xiao, G., Mao, J., \& Zheng, Y. (2016). Adaptive multisubpopulation competition and multiniche crowding-based memetic algorithm for automatic data clustering. IEEE transactions on evolutionary computation, 20(6), 838-858.

[18] Agárdi, A. (2021) Klasszikus klaszterező algoritmusok módosítása körút alapon, Multidiszciplináris Tudományok, 11(4), 81-86. https://doi.org/10.35925/j.multi.2021.4.9 


\section{Függelék}

F1. táblázat. Az adatsorok struktúrája

\begin{tabular}{|c|c|c|c|c|c|c|c|c|}
\hline \multicolumn{3}{|c|}{ Első adatsor } & \multicolumn{3}{|c|}{ Második adatsor } & \multicolumn{3}{|c|}{ Harmadik adatsor } \\
\hline & $\begin{array}{c}\text { Pontok } \\
\text { száma }\end{array}$ & $\begin{array}{c}\text { Opt. } \\
\text { klasz- } \\
\text { ter- } \\
\text { szám }\end{array}$ & & $\begin{array}{c}\text { Pontok } \\
\text { száma }\end{array}$ & $\begin{array}{c}\text { Opt. } \\
\text { klasz- } \\
\text { ter- } \\
\text { szám }\end{array}$ & & $\begin{array}{c}\text { Pontok } \\
\text { száma }\end{array}$ & $\begin{array}{c}\text { Opt. } \\
\text { klasz- } \\
\text { ter- } \\
\text { szám }\end{array}$ \\
\hline & 100 & 10 & & 50 & 5 & & 90 & 3 \\
\hline & \multicolumn{2}{|c|}{ Koordináták } & & \multicolumn{2}{|c|}{ Koordináták } & & \multicolumn{2}{|c|}{ Koordináták } \\
\hline $\begin{array}{l}\text { Sor- } \\
\text { Szám }\end{array}$ & $\mathbf{X}$ & $\mathbf{Y}$ & $\begin{array}{l}\text { Sor- } \\
\text { szám }\end{array}$ & $\mathbf{X}$ & $\mathbf{Y}$ & $\begin{array}{l}\text { Sor- } \\
\text { szám }\end{array}$ & $\mathbf{X}$ & $\mathbf{Y}$ \\
\hline 1 & 6,1747 & 7,6551 & 1 & 2,8828 & 3,7170 & 1 & 2,6909 & 1,3597 \\
\hline 2 & 6,1766 & 7,6399 & 2 & 2,8884 & 3,7239 & 2 & 2,7044 & 1,3668 \\
\hline 3 & 6,1759 & 7,6532 & 3 & 2,9260 & 3,7745 & 3 & 2,6695 & 1,3826 \\
\hline 4 & 6,1727 & 7,6522 & 4 & 2,8922 & 3,7484 & 4 & 2,6635 & 1,3672 \\
\hline 5 & 6,1487 & 7,6524 & 5 & 2,8987 & 3,7862 & 5 & 2,6848 & 1,3669 \\
\hline 6 & 6,1838 & 7,6685 & 6 & 2,9215 & 3,7523 & 6 & 2,7048 & 1,3063 \\
\hline 7 & 6,1945 & 7,6502 & 7 & 2,9584 & 3,7495 & 7 & 2,6501 & 1,3483 \\
\hline 8 & 6,1777 & 7,6753 & 8 & 2,9384 & 3,7541 & 8 & 2,6147 & 1,3337 \\
\hline 9 & 6,1788 & 7,6600 & 9 & 2,9279 & 3,7812 & 9 & 2,7033 & 1,3613 \\
\hline 10 & 6,1450 & 7,6291 & 10 & 2,9464 & 3,7241 & 10 & 2,6580 & 1,3118 \\
\hline 11 & 5,8577 & 8,4049 & 11 & 3,4392 & 2,7148 & 11 & 2,6753 & 1,3541 \\
\hline 12 & 5,8562 & 8,4080 & 12 & 3,4040 & 2,7042 & 12 & 2,7060 & 1,3686 \\
\hline 13 & 5,8678 & 8,4164 & 13 & 3,4185 & 2,6924 & 13 & 2,5899 & 1,3716 \\
\hline 14 & 5,8481 & 8,3926 & 14 & 3,4115 & 2,6881 & 14 & 2,6397 & 1,3220 \\
\hline 15 & 5,8549 & 8,4092 & 15 & 3,4060 & 2,6796 & 15 & 2,7344 & 1,2923 \\
\hline 16 & 5,8282 & 8,4076 & 16 & 3,4372 & 2,6760 & 16 & 2,6803 & 1,3813 \\
\hline 17 & 5,8339 & 8,4038 & 17 & 3,4004 & 2,6932 & 17 & 2,6825 & 1,3486 \\
\hline 18 & 5,8625 & 8,4144 & 18 & 3,4157 & 2,7131 & 18 & 2,6417 & 1,3677 \\
\hline 19 & 5,8466 & 8,4294 & 19 & 3,3990 & 2,6932 & 19 & 2,6955 & 1,3661 \\
\hline 20 & 5,8362 & 8,4264 & 20 & 3,4160 & 2,6564 & 20 & 2,6897 & 1,3266 \\
\hline 21 & 2,7416 & 1,5521 & 21 & 3,1182 & 4,2759 & 21 & 2,6628 & 1,3535 \\
\hline 22 & 2,7474 & 1,6199 & 22 & 3,1095 & 4,2815 & 22 & 2,6892 & 1,3356 \\
\hline 23 & 2,7480 & 1,5527 & 23 & 3,0920 & 4,2906 & 23 & 2,6644 & 1,3225 \\
\hline 24 & 2,7408 & 1,5840 & 24 & 3,1021 & 4,3071 & 24 & 2,6584 & 1,3723 \\
\hline 25 & 2,7878 & 1,5817 & 25 & 3,1182 & 4,2645 & 25 & 2,6778 & 1,3417 \\
\hline 26 & 2,7412 & 1,5510 & 26 & 3,1140 & 4,2731 & 26 & 2,6760 & 1,3564 \\
\hline 27 & 2,7228 & 1,5298 & 27 & 3,0935 & 4,3149 & 27 & 2,6435 & 1,3670 \\
\hline 28 & 2,7825 & 1,5871 & 28 & 3,1167 & 4,2763 & 28 & 2,6426 & 1,3531 \\
\hline 29 & 2,7259 & 1,5414 & 29 & 3,1078 & 4,2461 & 29 & 2,6651 & 1,3677 \\
\hline 30 & 2,8014 & 1,5797 & 30 & 3,0688 & 4,2591 & 30 & 2,7059 & 1,4088 \\
\hline 31 & 2,3693 & 6,0356 & 31 & 2,8662 & 1,4501 & 31 & 2,5191 & 0,8973 \\
\hline 32 & 2,4098 & 5,9884 & 32 & 2,9028 & 1,4467 & 32 & 2,5472 & 0,9295 \\
\hline 33 & 2,3676 & 5,9702 & 33 & 2,8893 & 1,4224 & 33 & 2,5457 & 0,8895 \\
\hline 34 & 2,3920 & 5,9900 & 34 & 2,9046 & 1,4510 & 34 & 2,5323 & 0,9056 \\
\hline 35 & 2,3940 & 6,0026 & 35 & 2,8938 & 1,4118 & 35 & 2,5177 & 0,9005 \\
\hline 36 & 2,3723 & 5,9780 & 36 & 2,9103 & 1,4746 & 36 & 2,5021 & 0,8991 \\
\hline
\end{tabular}




\begin{tabular}{|c|c|c|c|c|c|c|c|c|}
\hline 37 & 2,4065 & 5,9722 & 37 & 2,9066 & 1,3809 & 37 & 2,5219 & 0,9337 \\
\hline 38 & 2,3670 & 5,9665 & 38 & 2,8991 & 1,4097 & 38 & 2,5125 & 0,9106 \\
\hline 39 & 2,3617 & 6,0109 & 39 & 2,8938 & 1,4346 & 39 & 2,5243 & 0,9284 \\
\hline 40 & 2,4020 & 5,9420 & 40 & 2,8704 & 1,4476 & 40 & 2,5359 & 0,8883 \\
\hline 41 & 6,1124 & 9,0662 & 41 & 4,9346 & 0,3284 & 41 & 2,5291 & 0,8817 \\
\hline 42 & 6,1159 & 9,0881 & 42 & 4,9327 & 0,3169 & 42 & 2,4984 & 0,9241 \\
\hline 43 & 6,0968 & 9,0715 & 43 & 4,9339 & 0,3053 & 43 & 2,5392 & 0,9256 \\
\hline 44 & 6,1284 & 9,0684 & 44 & 4,9204 & 0,3215 & 44 & 2,5444 & 0,9059 \\
\hline 45 & 6,1021 & 9,0772 & 45 & 4,9462 & 0,2683 & 45 & 2,5482 & 0,9248 \\
\hline 46 & 6,1036 & 9,0856 & 46 & 4,9178 & 0,2724 & 46 & 2,5313 & 0,9135 \\
\hline 47 & 6,0831 & 9,0809 & 47 & 4,8839 & 0,2756 & 47 & 2,5203 & 0,9341 \\
\hline 48 & 6,1155 & 9,0635 & 48 & 4,9317 & 0,2674 & 48 & 2,5598 & 0,9353 \\
\hline 49 & 6,1232 & 9,0971 & 49 & 4,9166 & 0,2888 & 49 & 2,5356 & 0,9366 \\
\hline 50 & 6,1286 & 9,0879 & 50 & 4,8755 & 0,3340 & 50 & 2,5275 & 0,9090 \\
\hline 51 & 6,1730 & 0,2722 & & & & 51 & 2,5038 & 0,8974 \\
\hline 52 & 6,1723 & 0,2721 & & & & 52 & 2,5542 & 0,9075 \\
\hline 53 & 6,2176 & 0,2776 & & & & 53 & 2,5849 & 0,9140 \\
\hline 54 & 6,1786 & 0,2746 & & & & 54 & 2,5420 & 0,9164 \\
\hline 55 & 6,1874 & 0,3247 & & & & 55 & 2,5382 & 0,9230 \\
\hline 56 & 6,1721 & 0,2855 & & & & 56 & 2,5767 & 0,9287 \\
\hline 57 & 6,1513 & 0,3033 & & & & 57 & 2,5219 & 0,8947 \\
\hline 58 & 6,1952 & 0,3011 & & & & 58 & 2,5425 & 0,8788 \\
\hline 59 & 6,1537 & 0,2582 & & & & 59 & 2,5601 & 0,8985 \\
\hline 60 & 6,1904 & 0,2779 & & & & 60 & 2,5131 & 0,9503 \\
\hline 61 & 3,8704 & 1,1179 & & & & 61 & 1,6374 & 0,4241 \\
\hline 62 & 3,8238 & 1,1261 & & & & 62 & 1,6407 & 0,4343 \\
\hline 63 & 3,8305 & 1,0743 & & & & 63 & 1,6461 & 0,4376 \\
\hline 64 & 3,8341 & 1,0982 & & & & 64 & 1,5938 & 0,4320 \\
\hline 65 & 3,8364 & 1,1377 & & & & 65 & 1,6477 & 0,4165 \\
\hline 66 & 3,8383 & 1,0193 & & & & 66 & 1,6643 & 0,4019 \\
\hline 67 & 3,8719 & 1,0776 & & & & 67 & 1,6304 & 0,4431 \\
\hline 68 & 3,8337 & 1,1343 & & & & 68 & 1,6349 & 0,4156 \\
\hline 69 & 3,8182 & 1,0947 & & & & 69 & 1,6347 & 0,4233 \\
\hline 70 & 3,8583 & 1,0800 & & & & 70 & 1,6235 & 0,4089 \\
\hline 71 & 0,7362 & 5,5913 & & & & 71 & 1,6413 & 0,4596 \\
\hline 72 & 0,6905 & 5,5682 & & & & 72 & 1,6103 & 0,4289 \\
\hline 73 & 0,7203 & 5,5412 & & & & 73 & 1,6227 & 0,4262 \\
\hline 74 & 0,7217 & 5,5878 & & & & 74 & 1,6069 & 0,4551 \\
\hline 75 & 0,7637 & 5,5910 & & & & 75 & 1,6117 & 0,4387 \\
\hline 76 & 0,7172 & 5,5837 & & & & 76 & 1,6296 & 0,4232 \\
\hline 77 & 0,6774 & 5,5477 & & & & 77 & 1,6118 & 0,3922 \\
\hline 78 & 0,7192 & 5,6092 & & & & 78 & 1,6356 & 0,4160 \\
\hline 79 & 0,7490 & 5,5281 & & & & 79 & 1,5738 & 0,4266 \\
\hline 80 & 0,6756 & 5,6200 & & & & 80 & 1,6279 & 0,4321 \\
\hline 81 & 5,3902 & 7,0243 & & & & 81 & 1,6582 & 0,3973 \\
\hline 82 & 5,4321 & 6,9798 & & & & 82 & 1,6252 & 0,4437 \\
\hline 83 & 5,4190 & 6,9831 & & & & 83 & 1,6185 & 0,4062 \\
\hline 84 & 5,3863 & 7,0288 & & & & 84 & 1,6305 & 0,4404 \\
\hline
\end{tabular}




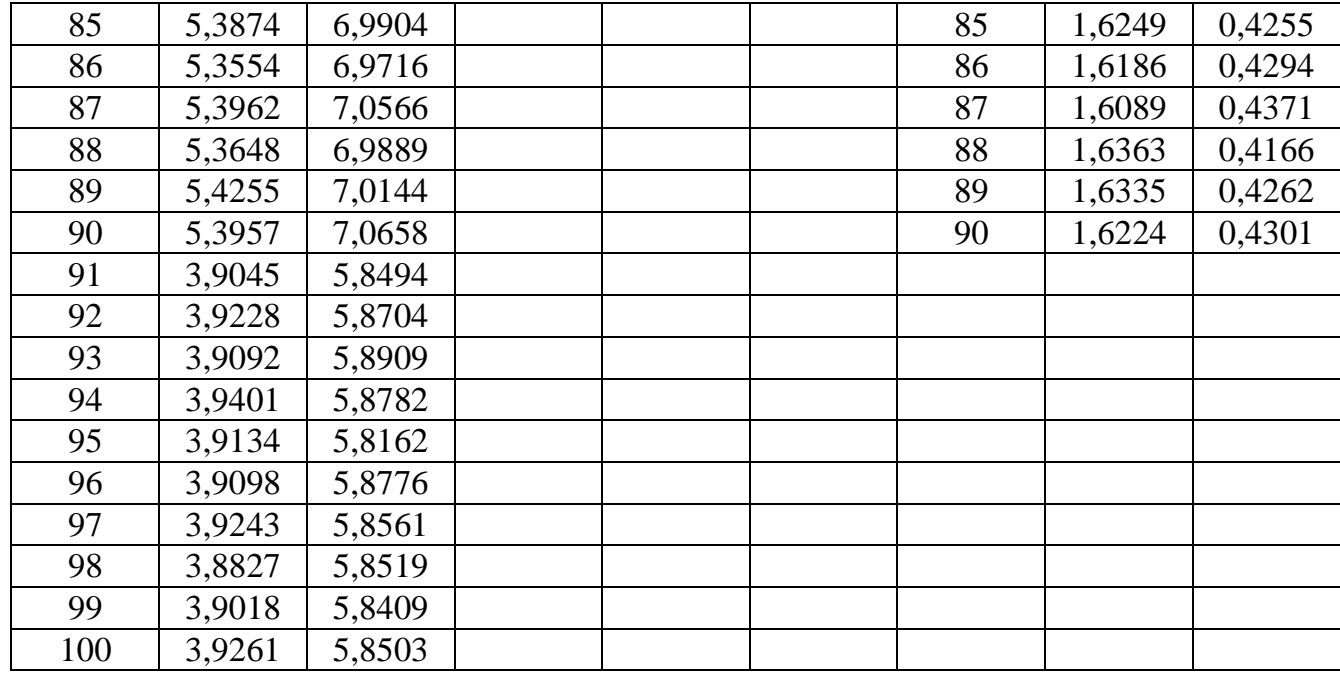

